\title{
A novel $P A L B 2$ truncating mutation in an Italian family with male breast cancer
}

\author{
MARIA TERESA VIETRI, GEMMA CALIENDO, AMELIA CASAMASSIMI, MICHELE CIOFFI, \\ MARIA LAURA DE PAOLA, CLAUDIO NAPOLI and ANNA MARIA MOLINARI \\ Department of Biochemistry, Biophysics and General Pathology, School of Medicine, \\ Second University of Naples, I-80138 Naples, Italy
}

Received May 12, 2014; Accepted July 21, 2014

DOI: $10.3892 /$ or.2014.3685

\begin{abstract}
Male breast cancer (MBC) is a rare disease, accounting for $\sim 1 \%$ of all breast cancer cases worldwide. Although other genes are also involved, predisposing genetic factors to $\mathrm{MBC}$ include germline mutations in the $B R C A$ genes (BRCA2). Among the other genes, partner and localizer of BRCA2 (PALB2) is considered a moderate-penetrance breast cancer susceptibility gene that may also play a role in MBC predisposition. Thus, the aim of the present study was to determine the PALB2 gene status in $8 \mathrm{MBC}$ cases selected from a cohort of 181 hereditary breast and/or ovarian cancer probands. We performed $P A L B 2$ mutational analysis by direct sequencing of 13 exons and adjacent intronic regions. This study showed the presence of a PALB2 truncating mutation in $1 / 8(12.5 \%)$ cases. This novel mutation was named c.1285_1286delAinsTC (p.I429SfsX12) and is localized in exon 4 of $P A L B 2$, in the region encoding for the ChAM motif which is important for the efficient association of $P A L B 2$ to chromatin and for recruitment of the BRCA complex to accumulate RAD51 at double-strand break sites. Our findings indicate that $P A L B 2$ could be added to the list of breast cancer susceptibility genes also in families with MBC cases.
\end{abstract}

\section{Introduction}

Breast cancer in men is a rare disease, accounting for $\sim 1 \%$ of all breast cancer cases worldwide (1). An important predisposing genetic factor for male breast cancer (MBC) includes germline mutations in the $B R C A$ genes, particularly in $B R C A 2$, although other genes are implicated (2). Partner and localizer of BRCA2 (PALB2) is the third hereditary breast cancer

Correspondence to: Dr Maria Teresa Vietri, Department of Biochemistry, Biophysics and General Pathology, School of Medicine, Second University of Naples, 7 Via Luigi De Crecchio, I-80138 Naples, Italy

E-mail: mariateresa.vietri@unina2.it

Key words: $P A L B 2$, male breast cancer, hereditary breast cancer, $B R C A$ genes susceptibility gene; it is mutated in approximately $1-2 \%$ of cases, with higher rates in certain populations $(3,4)$.

$P A L B 2$ is also the second most commonly mutated gene noted in hereditary pancreatic cancer (5). Indeed, deleterious germline $P A L B 2$ mutations have been reported in families with breast and pancreatic cancer from the USA (6) and Europe $(7,8)$.

Other studies have reported that various $P A L B 2$ mutations also predispose to hereditary prostate cancer $(9,10)$.

The role of $P A L B 2$ in MBC predisposition still remains to be clarified. Several studies have reported truncating mutations of $P A L B 2$ in cases of MBC (11-14). In contrast, no evidence of $P A L B 2$ pathogenic mutations in $\mathrm{MBC}$ was found in other studies (15-17).

Thus, the aim of the present study was to determine the prevalence of $P A L B 2$ mutations in Italian families with at least one male breast cancer case.

\section{Patients and methods}

Patients. We selected 8 patients affected with MBC, or who had at least one $\mathrm{MBC}$ case in the pedigree, from a group of 181 patients affected with hereditary breast and/or ovarian cancer from Campania, a region of southern Italy. Of the patients, 5 were males with breast cancer and 3 were females with breast cancer who had a first-degree relative with MBC. Patients were selected according to the selection criteria for hereditary breast cancer based on the Breast Cancer Linkage Consortium (18).

Ethics committee approval was obtained for the study. Informed consent for molecular analysis was obtained from all subjects, and the main clinical and histopathological data were generated by genetic counseling. Peripheral blood samples were collected from all patients.

All patients were previously screened for $B R C A I$ and BRCA2 mutations.

Mutation analysis. Genomic DNA was isolated from peripheral blood lymphocytes, using the Wizard Genomic DNA purification kit (Promega Corporation, Madison, WI, USA) according to the manufacturer's instructions.

$P A L B 2$ mutational analysis was conducted by direct sequencing of 13 exons and adjacent intronic regions. One set 


\begin{tabular}{|c|c|c|c|c|c|}
\hline Gene & Exon & mRNA nt & Base change & Protein change & Mutation type \\
\hline PALB2 & 4 & $1285 \_1286$ & delAinsTC & I429SfsX12 & frameshift \\
\hline
\end{tabular}

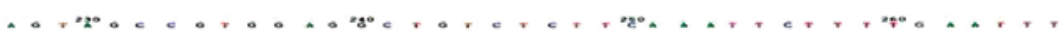

A

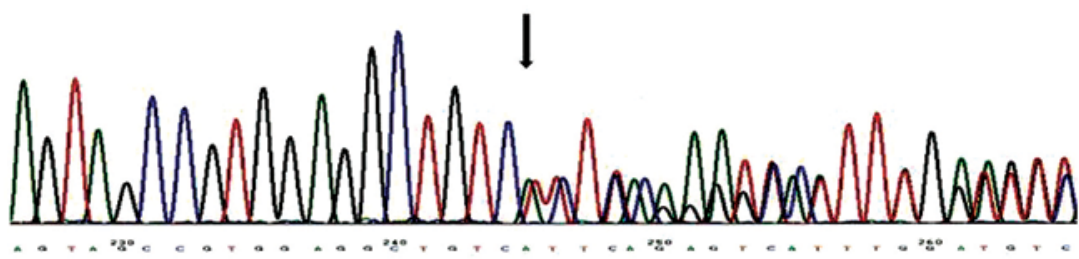

B

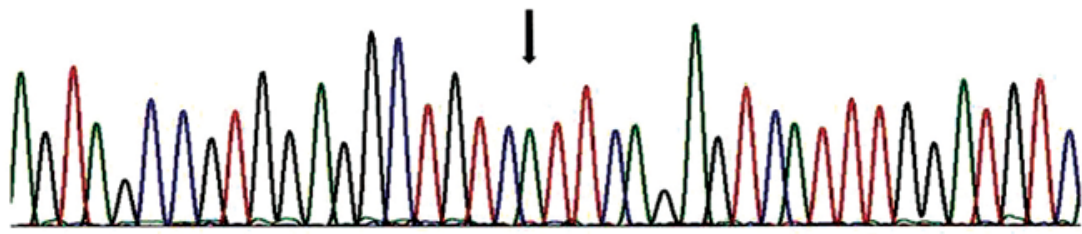

Figure 1. Partial electropherogram of PALB2 exon 4. The novel mutation identified as c.1285_1286delAinsTC (p.I429SfsX12) results in chain termination at codon 441. (A) Electropherogram of the patient reveals the A deletion and TC insertion. (B) The wild-type sequence.

of primers was used to amplify each exon, except for exons 4 and 5, which were amplified in four and two PCR products, respectively.

The primers used to amplify the coding exon-intron boundaries of $P A L B 2$, were previously reported (19).

All PCR products were sequenced on both strands using the ABI Prism di-Deoxy Terminator Cycle Sequencing kit in the ABI 9700 thermal cycler and an ABI Prism 3100 automatic sequencer (both from Life Technologies, Carlsbad, CA, USA). The results were analyzed using Mutation Surveyor ${ }^{\circledR}$ software, version 3.24 (Softgenetics, State College, PA, USA).

GenBank reference sequences used for naming the novel mutation were NM_024675.3 and NT_010393.15. The sequence variant was named and referred to in the text according to the nomenclature used by the Human Genome Variation Society (HGVS; http://www.hgvs.org), using the descriptions suggested by den Dunnen and Antonarakis (20).

RNA analysis. The patient with the novel mutation was subjected to a second peripheral blood sample, to confirm the presence of the mutation also in mRNA.

Total-RNA was isolated from peripheral blood lymphocytes using TRIzol reagent and reverse transcribed with SuperScript First-Strand Synthesis System (both from Life Technologies) according to the manufacturer's protocol.

From our set of primers used for the mutation analysis, we selected a forward primer in exon 4 and a reverse primer in exon 5 to amplify from total cDNA the region spanning the mutation. The RT-PCR product was electrophoresed on agarose gel and then sequenced.

\section{Results}

We observed 8 cases of MBC in a cohort of 181 hereditary breast and/or ovarian cancer probands. The prevalence of MBC in our group of patients was $4.4 \%$.

Mutation analysis of the $P A L B 2$ gene showed the presence of a mutation in $1 / 8(12.5 \%)$ breast cancer patients. This mutation, not previously described, was named c.1285_1286delAinsTC (p.I429SfsX12). It was localized within exon 4 and consisted of an A deletion and TC insertion at position c.1285_1286, which shifted the reading frame at the 429 codon and led to a premature termination 12 codon downstream, at codon 441 (Fig. 1).

The presence of the mutation was confirmed by resequencing a second DNA sample from the patient. RNA analysis showed the same mutation.

In Table I, we document the clinical and histopathological characteristics of the 8 analyzed patients.

The c.1285_1286delAinsTC (p.I429SfsX12) mutation was identified in a 30-year-old woman affected with hereditary breast cancer, with one MBC case in the family. The pedigree is reported in Fig. 2. This family showed multiple affected members of the same disease. Breast cancer was diagnosed in the patient at the age of 29, her father at the age of 60 and two sisters at the age of 31 and 34 years, respectively; in addition a paternal aunt with breast cancer died at 40 years of age.

Molecular testing for $P A L B 2$ was performed in the father and in one of the two sisters that agreed with testing. The analysis showed that both subjects were carriers of this mutation.

\section{Discussion}

PALB2, the partner and localizer of BRCA2, binds BRCA1 and BRCA2 to promote efficient DNA repair by homologous recombination (21).

$P A L B 2$ is a moderate penetration breast cancer susceptibility gene with a variable estimated risk of breast cancer. The Finnish founder c.1952delT mutation increased the risk of breast cancer 6-fold by the age of 70 years (22), and five PALB2 mutations reported in the UK confer a 2.3-fold increased risk of breast cancer (23).

We found a novel PALB2 truncating mutation in an Italian family with an MBC case. Few studies have analyzed the $P A L B 2$ status in MBC. Particularly, in Italy, only one study has been conducted (16). In this study, based on a series of 108 MBC cases, of which 97 cases were BRCA1/2-negative, 
Table I. Mutation and receptor status of patients affected with $\mathrm{MBC}$ or with $\mathrm{BC}$ and $\mathrm{MBC}$ cases in the family.

\begin{tabular}{|c|c|c|c|c|c|c|}
\hline $\begin{array}{l}\text { Patient } \\
\text { no. }\end{array}$ & Gender & $\begin{array}{c}\text { Age at } \\
\text { diagnosis } \\
\text { (years) }\end{array}$ & Diagnosis & $\begin{array}{l}\text { Receptor } \\
\text { status }\end{array}$ & $\begin{array}{l}B R C A 1 / 2 \\
\text { mutation }\end{array}$ & $\begin{array}{l}P A L B 2 \\
\text { mutation }\end{array}$ \\
\hline 1 & M & 65 & MBC & $\mathrm{ER}^{+} / \mathrm{PR}^{+} / \mathrm{HER} 2^{-}$ & - & - \\
\hline 2 & M & 83 & MBC & $\mathrm{ER}^{+} / \mathrm{PR}^{+} / \mathrm{HER} 2^{-}$ & - & - \\
\hline 3 & M & 69 & MBC & $\mathrm{ER}^{+} / \mathrm{PR}^{+} / \mathrm{HER}^{-}$ & $\mathrm{UV}$ in $B R C A 2$ & - \\
\hline 4 & M & 40 & MBC & $\mathrm{ER}^{+} / \mathrm{PR}^{+} / \mathrm{HER} 2^{-}$ & $\mathrm{UV}$ in $B R C A 2$ & - \\
\hline 5 & M & 58 & MBC & $\mathrm{ER}^{+} / \mathrm{PR}^{+} / \mathrm{HER} 2^{-}$ & $\mathrm{UV}$ in $B R C A 2$ & - \\
\hline 6 & $\mathrm{~F}$ & 29 & BC (father MBC) & ER-/PR-/HER2- & - & $\begin{array}{c}\text { c.1285_1286delAinsTC } \\
\text { (p.I429SfsX12) }\end{array}$ \\
\hline 7 & $\mathrm{~F}$ & 29 & BC (grandfather MBC) & $\mathrm{ER}^{+} / \mathrm{PR}^{-} / \mathrm{HER} 2^{+}$ & - & - \\
\hline 8 & $\mathrm{~F}$ & 38 & BC (grandfather MBC) & $\mathrm{ER}^{-} / \mathrm{PR}^{-} / \mathrm{HER} 2^{-}$ & $5382 \mathrm{ins} C$ in $B R C A 1$ & - \\
\hline
\end{tabular}

F, female; M, male; MBC, male breast cancer; BC, breast cancer; UV, unclassified variant; ER, estrogen receptor; PG, progesterone receptor; HER2, human epidermal growth factor receptor 2.

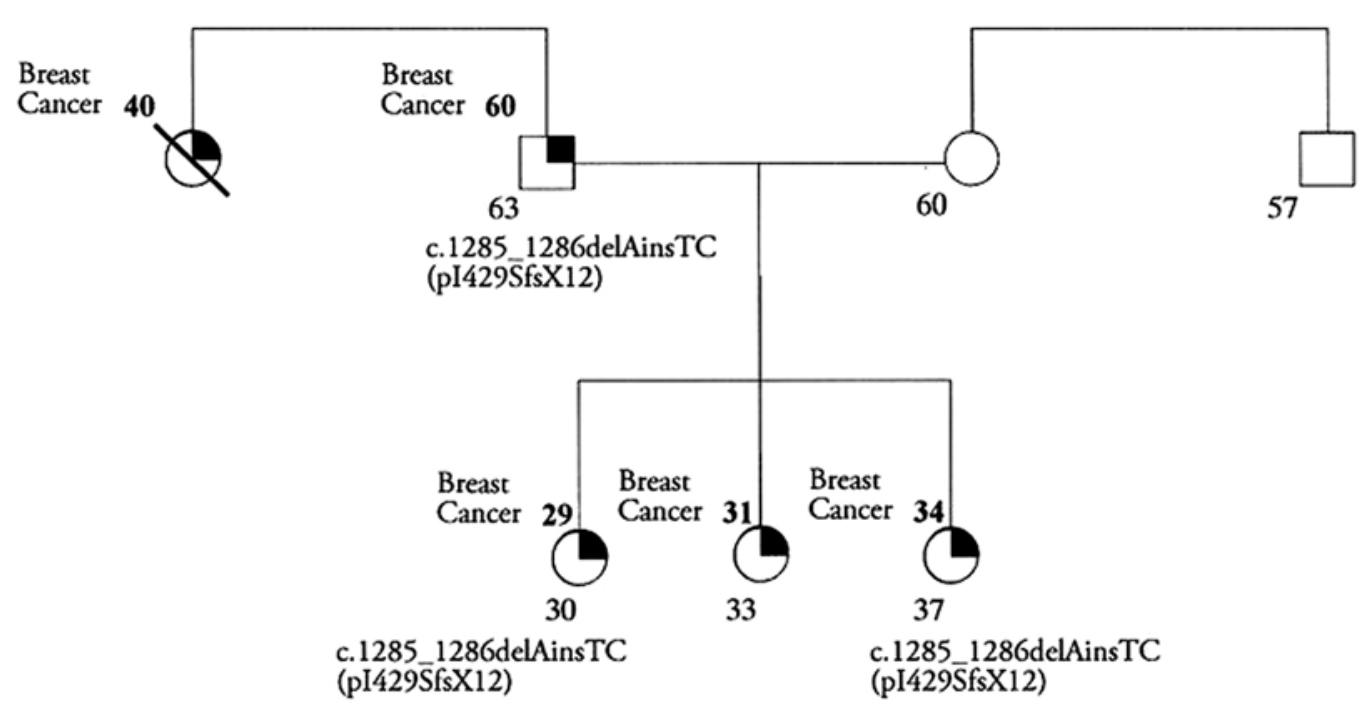

Figure 2. Pedigree of the breast cancer family carrying the PALB2 mutation c.1285_1286delAinsTC (pI429SfsX12). The age at diagnosis or death for each patient is indicated.

no PALB2 mutation was found (16). In contrast, we found a mutation in $1 / 8(12.5 \%)$ patients. The high frequency of the PALB2 mutation observed in our study was similar to that described in a US study that reported two truncating mutations in 13 proband males (16\%) (12), whereas other authors showed a lower rate, ranging from 1 to $9 \%(11,13,14)$. In agreement with these studies, we confirmed the presence of the PALB2 mutations in $\mathrm{MBC}$ cases, suggesting that $P A L B 2$ might play an important role in hereditary MBC.

Most of the truncating mutations previously reported were mapped to exons 4 and 5 of the $P A L B 2$ gene, probably as they are the largest two exons in PALB2 (24). Importantly, all of the mutations discovered in a Chinese population occurred in exons 4 of $P A L B 2$, suggesting a potential hotspot (25). The c.1285_1286delAinsTC (p.I429SfsX12) mutation is localized in exon 4, whereas other Italian studies reported the PALB2 mutations localized in exon 4 and $5(26,27)$, as well as in exon 2 and 13 (8), suggesting no mutational hot spot in the $P A L B 2$ gene for the Italian population.

To map the BRCA1-interacting region in PALB2, 13 internal deletion mutants of PALB2 were generated with the P1 mutant, deleted for amino acids 6-90, that failed to associate with BRCA1 (28). These results showed that PALB2 protein has a coiled-coil motif at the $\mathrm{N}$ terminus, required for interaction with BRCA1 (Fig. 3). Other biochemical studies showed that PALB2 binds DNA via two separate regions in the $\mathrm{N}$-terminus of the protein, called PALB2 truncation 1 (P2T1) and PALB2 truncation 3 (P2T3), respectively $(29,30)$. Particularly, P2T3 contains an evolutionarily conserved PALB2 motif, named chromatin-association motif (ChAM), which is 


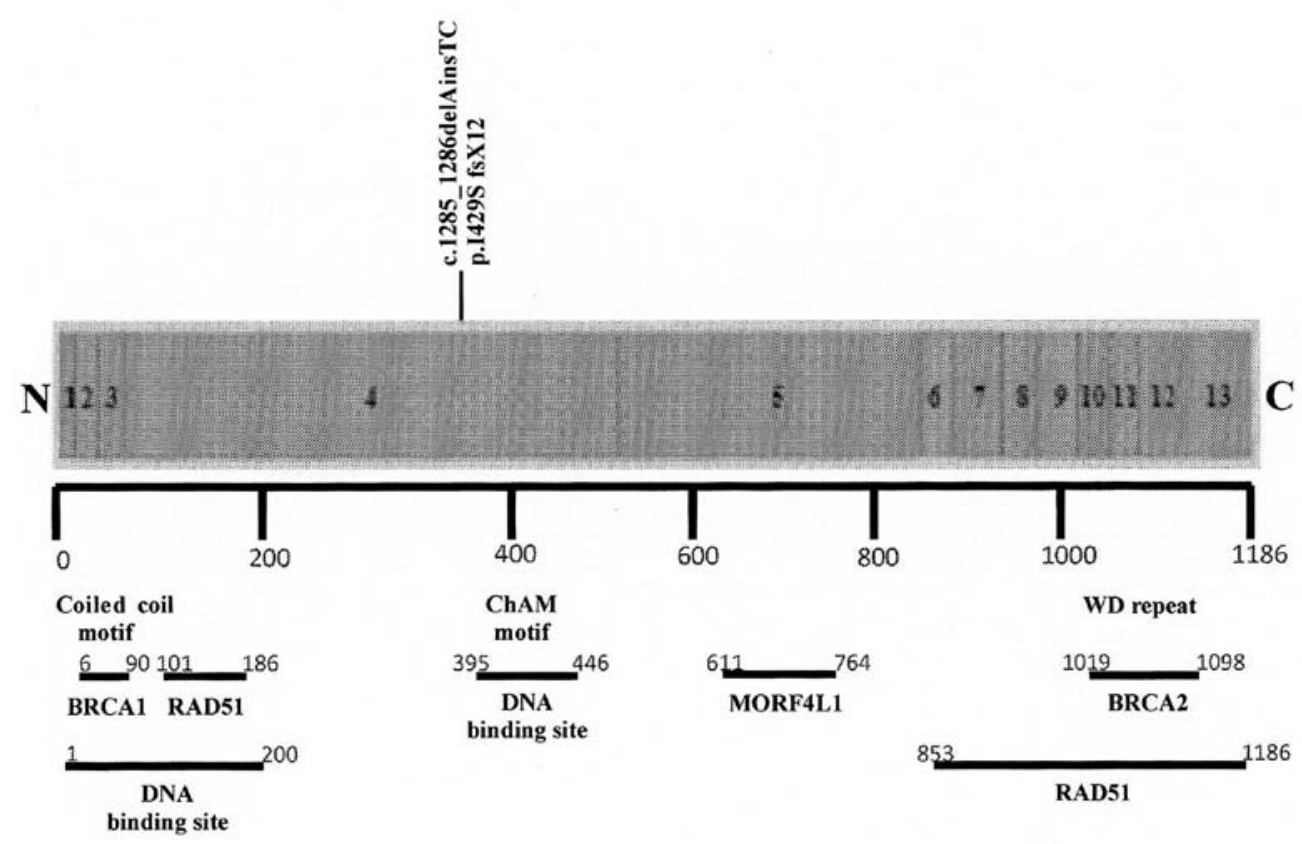

Figure 3. Schematic structure of PALB2 with localization of the binding sites with other proteins. The mutation c.1285_1286delAinsTC (p.I429SfsX12) is localized in the ChAM motif.

localized at amino acid region 395-446. ChAM is important for the efficient association of PALB2 to chromatin and for recruitment of the BRCA complex to accumulate RAD51 at double-strand break sites (31). Furthermore, the amino acidic region 611-764 of PALB2 interacts with mortality factor 4 like protein 1 (MORF4L1) which is important for promoting the function of the BRCA complex. PALB2 interacts with RAD51 by two regions (amino acids 101-184 and 853-1186) and has a C-terminal domain, containing four WD repeats which mediate the interaction with BRCA2 (32).

The novel mutation c.1285_1286delAinsTC (p.I429SfsX12) was found to be localized in exon 4 of $P A L B 2$, in the region that encodes for the ChAM motif (Fig. 3). It introduces a premature stop at codon 441 position; therefore, it may be expected that this mutation reduces the capacity of the ChAM motif for mediating PALB2 chromatin association thus altering DNA damage repair processes. In addition, this mutation induces the lack of interaction between MORF4L1 and BRCA2.

The prevalence of MBC in our patients was $4.4 \%$ in agreement with other studies that reported frequencies ranging from 4.1 to $4.6 \%$ (1). Out of 7 breast cancer patients, negative for $P A L B 2$ mutations, one was a carrier of the 5382insC mutation in $B R C A 1$, as previously reported in our study (33). Instead, 3 MBC cases were carriers of unclassified variants in $B R C A 2$ (Table I). However, the patients with the BRCA1 mutation or with unclassified variants in $B R C A 2$ were additionally tested for a $P A L B 2$ mutation in order to not underestimate a possible condition of double heterozygosity (DH) in the $B R C A$ and $P A L B 2$ genes. In a recent study, Pern et al described DH for $B R C A 1$ and $P A L B 2$ mutations in one German patient with triple-negative breast cancer (34).

On the basis of our findings, PALB2 could be added to the list of breast cancer susceptibility genes, not only in families with recurring breast and pancreatic cancers but also in families with MBC.

\section{Acknowledgements}

The authors thank Mrs. Anna Cuomo for technical assistance in the mutation analysis.

\section{References}

1. Ottini L, Palli D, Rizzo S, Federico M, Bazan V and Russo A: Male breast cancer. Crit Rev Oncol Hematol 73: 141-155, 2010.

2. Mohamad HB and Apffelstaedt JP: Counseling for male BRCA mutation carriers: a review. Breast 17: 441-450, 2008.

3. Erkko H, Dowty JG, Nikkilä J, Syrjäkoski K, Mannermaa A, Pylkäs K, Southey MC, Holli K, Kallioniemi A, JukkolaVuorinen A, Kataja V, Kosma VM, Xia B, Livingston DM, Winqvist R and Hopper JL: Penetrance analysis of the PALB2 c.1592delT Founder mutation. Clin Cancer Res 14: 4667-4671, 2008.

4. Foulkes WD, Ghadirian P, Akbari MR, Hamel N, Giroux S, Sabbaghian N, Darnel A, Royer R, Poll A, Fafard E, Robidoux A, Martin G, Bismar TA, Tischkowitz M, Rousseau F and Narod SA: Identification of a novel truncating PALB2 mutation and analysis of its contribution to early-onset breast cancer in French-Canadian women. Breast Cancer Res 9: R83, 2007.

5. Jones S, Hruban RH Kamiyama M, et al: Exomic sequencing identifies PALB2 as a pancreatic cancer susceptibility gene. Science 324: 217, 2009.

6. Hofstatter EW, Domchek SM, Miron A, Garber J, Wang M, Componeschi K, Boghossian L, Mitron PL, Nathanson KL and Tung N: PALB2 mutations in familial breast and pancreatic cancer. Fam Cancer 10: 225-231, 2011.

7. Slater EP, Langer P, Niemczyk E, Strauch K, Butler J, Habbe N, Neoptolemos JP, Greenhalf W and Bartsch DK: PALB2 mutations in European familial pancreatic cancer families. Clin Genet 78: 490-494, 2010.

8. Peterlongo P, Catucci I, Pasquini G, Verderio P, Peissel B, Barile M, Varesco L, Riboni M, Fortuzzi S, Manoukian S and Radice P: PALB2 germline mutations in familial breast cancer cases with personal and family history of pancreatic cancer. Breast Cancer Res Treat 126: 825-828, 2011.

9. Tischkowitz M, Sabbaghian N, Ray AM, Lange EM, Foulkes WD and Cooney KA: Analysis of the gene coding for the BRCA2-interacting protein PALB2 in hereditary prostate cancer. Prostate 68: 675-678, 2008. 
10. Pakkanen S, Wahlfors T, Siltanen S, Patrikainen M, Matikainen MP, Tammela TL and Schleutker J: PALB2 variants in hereditary and unselected Finnish prostate cancer cases. J Negat Results Biomed 8: 12, 2009.

11. García MJ, Fernández V, Osorio A, Barroso A, Llort G, Lázaro C, Blanco I, Caldés T, de la Hoya M, Ramón Y Cajal T, Alonso C, Tejada MI, San Román C, Robles-Díaz L, Urioste M and Benítez J: Analysis of FANCB and FANCN/PALB2 Fanconi anemia genes in BRCA1/2-negative Spanish breast cancer families. Breast Cancer Res Treat 113: 545-1551, 2009.

12. Casadei S, Norquist BM, Walsh T, Stray S, Mandell JB, Lee MK, Stamatoyannopoulos JA and King MC: Contribution of inherited mutations in the BRCA2-interacting protein PALB2 to familial breast cancer. Cancer Res 71: 2222-2229, 2011.

13. Ding YC, Steele L, Kuan CJ, Greilac S and Neuhausen SL: Mutations in BRCA2 and PALB2 in male breast cancer cases from the United States. Breast Cancer Res Treat 6: 771-778, 2011

14. Adank MA, van Mil SE, Gille JJ, Waisfisz Q and MeijersHeijboer H: PALB2 analysis in BRCA2-like families. Breast Cancer Res Treat 127: 357-362, 2011.

15. Sauty de Chalon A, Teo Z, Park DJ, Odefrey FA, Hopper JL and Southey MC: Are PALB2 mutations associated with increased risk of male breast cancer? Breast Cancer Res Treat 121: 253-255, 2010.

16. Silvestri V, Rizzolo P, Zanna I, Falchetti M, Masala G, Bianchi S, Papi L, Giannini G, Palli D and Ottini L: PALB2 mutations in male breast cancer: a population-based study in Central Italy. Breast Cancer Res Treat 122: 299-301, 2010.

17. Blanco A, de la Hoya M, Balmaña J, Ramón y Cajal T, Teulé A, Miramar MD, Esteban E, Infante M, Benítez J, Torres A, Tejada MI, Brunet J, Graña B, Balbín M, Pérez-Segura P, Osorio A, Velasco EA, Chirivella I, Calvo MT, Feliubadaló L, Lasa A, Díez O, Carracedo A and Vega A: Detection of a large rearrangement in PALB2 in Spanish breast cancer families with male breast cancer. Breast Cancer Res Treat 132: 307-315, 2012

18. Breast Cancer Linkage Consortium: Pathology of familial breas cancer: differences between breast cancers in carriers of BRCA1 or BRCA2 mutations and sporadic cases. Lancet 349: 1505-1510, 1997.

19. Tischkowitz M, Xia B, Sabbaghian N, Reis-Filho JS, Hamel N, Li G, van Beers EH, Li L, Khalil T, Quenneville LA, Omeroglu A, Poll A, Lepage P, Wong N, Nederlof PM, Ashworth A, Tonin PN Narod SA, Livingston DM and Foulkes WD: Analysis of PALB2/FANCN-associated breast cancer families. Proc Natl Acad Sci USA 104: 6788-6793, 2007.

20. den Dunnen JT and Antonarakis SE: Mutation nomenclature. Curr Protoc Hum Genet: Chapter 7: Unit 7.13, 2003. doi: 10.1002/0471142905.ho0713s37.

21. Apostolou P and Fostira F: Hereditary breast cancer: the era of new susceptibility genes. Biomed Res Int: 2013: 747318, 2013. doi: $10.1155 / 2013 / 747318$.

22. Erkko H, Xia B, Nikkilä J, Schleutker J, Syrjäkoski K, Mannermaa A, Kallioniemi A, Pylkäs K, Karppinen SM, Rapakko K, Miron A, Sheng Q, Li G, Mattila H, Bell DW, Haber DA, Grip M, Reiman M, Jukkola-Vuorinen A, Mustonen A, Kere J, Aaltonen LA, Kosma VM, Kataja V, Soini Y, Drapkin RI, Livingston DM and Winqvist R: A recurrent mutation in PALB2 in Finnish cancer families. Nature 446: 316-319, 2007.
23. Rahman N, Seal S, Thompson D, Kelly P, Renwick A, Elliott A Reid S, Spanova K, Barfoot R, Chagtai T, Jayatilake H, McGuffog L, Hanks S, Evans DG, Eccles D, Breast Cancer Susceptibility Collaboration (UK), Easton DF and Stratton MR: PALB2, which encodes a BRCA2-interacting protein, is a breast cancer susceptibility gene. Nat Genet 39: 165-167, 2007.

24. Zheng Y, Zhang J, Niu Q, Huo D and Olopade OI: Novel germline PALB2 truncating mutations in African American breast cancer patients. Cancer 118: 1362-1370, 2012.

25. Cao AY, Huang J, Hu Z, Li WF, Ma ZL, Tang LL, Zhang B, Su FX, Zhou J, Di GH, Shen KW, Wu J, Lu JS, Luo JM, Yuan WT, Shen ZZ, Huang W and Shao ZM: The prevalence of PALB2 germline mutations in BRCA1/BRCA2 negative Chinese women with early onset breast cancer or affected relatives. Breast Cancer Res Treat 114: 457-462, 2009.

26. Balia C, Sensi E, Lombardi G, Roncella M, Bevilacqua G and Caligo MA. PALB2: a novel inactivating mutation in a Italian breast cancer family. Fam Cancer 9: 531-536, 2010.

27. Papi L, Putignano AL, Congregati C, Piaceri I, Zanna I, Sera F, Morrone D, Genuardi $M$ and Palli D: A PALB2 germline mutation associated with hereditary breast cancer in Italy. Fam Cancer 9: 181-185, 2010.

28. Zhang F, Ma J, Wu J, Ye L, Cai H, Xia B and Yu X: PALB2 links BRCA1 and BRCA2 in the DNA-damage response. Curr Biol 119: 524-529, 2009.

29. Buisson R, Dion-Côté AM, Coulombe Y, Launay H, Cai H, Stasiak AZ, Stasiak A, Xia B and Masson JY: Cooperation of breast cancer proteins PALB2 and piccolo BRCA2 in stimulating homologous recombination. Nat Struct Mol Biol 17: 1247-1254, 2010.

30. Dray E, Etchin J, Wiese C, Saro D, Williams GJ, Hammel M, Yu X, Galkin VE, Liu D, Tsai MS, Sy SM, Schild D, Egelman E, Chen $\mathrm{J}$ and Sung P: Enhancement of RAD51 recombinase activity by the tumor suppressor PALB2. Nat Struct Mol Biol 17: 1255-1259, 2010.

31. Bleuyard JY, Buisson R, Masson JY and Esashi F: ChAM, a novel motif that mediates PALB2 intrinsic chromatin binding and facilitates DNA repair. EMBO Rep 13: 135-141, 2012.

32. Southey MC Southey MC, Teo ZL and Winship I: PALB2 and breast cancer: ready for clinical translation! Appl Clin Genet 6 : 43-52, 2013

33. Vietri MT, Molinari AM, Laura De Paola M, Cantile F, Fasano M and Cioffi M: Identification of a novel in-frame deletion in BRCA 2 and analysis of variants of BRCA1/2 in Italian patients affected with hereditary breast and ovarian cancer. Clin Chem Lab Med 50: 2171-2180, 2012.

34. Pern F, Bougdanova N, Schurmann P, Lin M, Ay A, Langer F, Hillemanns P, Christiansen H, Park-Simon TW and Dörk T: Mutation analysis of BRCA1, BRCA2, PALB2 and BRD7 in a hospital-based series of German patients with triple negative breast cancer. PLoS One 7: e47993, 2012. 